\title{
Problem prostytucji w średniowiecznym Krakowie. Jana Falkenberga \\ Iudicium de aedificandis domis pro meretricibus
}

Prostytucja, uważana potocznie za „najstarszy zawód świata”, występowała i przybierała najróżniejsze formy właściwie we wszystkich kulturach. Różnorako się do niej odnoszono, czasami była akceptowana i wspierana, niekiedy z różnych powodów tolerowana, była też negowana. Istniała w postaci nierządu sakralnego, w niektórych kulturach była łączona z prawem gościnności, najczęściej jednak jedynym powodem jej istnienia było szukanie zaspokojenia nieuporządkowanych pożądań1. Prawo Mojżeszowe zabraniało prostytucji². Prawodawstwo Egiptu, Mezopotamii, Grecji i Rzymu odnosiło się do sprzedawania seksualności pozytywnie. Stanowisko chrześcijańskie od samego początku było negacją nierządu za pieniądze. Widziało $\mathrm{w}$ nim zwyczaje pogan, którzy albo w ogóle nie znają prawdziwego Boga, albo odwrócili się od Niego ${ }^{3}$. Od samego początku Kościoła dziewictwo cieszyło się niezwykłym szacunkiem, niespotykanym gdzie indziej. Przykład Chrystusa czy Jego Matki, św. Pawła, św. Jana, św. Jana Chrzciciela, świętych dziewic męczennic miał ogromny wpływ na kształtowanie postaw moralnych ${ }^{4}$. Nie oznaczało to negacji seksualności, o czym świadczy nieustanna walka Kościoła z takimi prądami w gnozie. Jednakże dobrowolne dziewictwo dla Królestwa niebieskiego jest uznawane od początku Kościoła za doskonalszą for-

${ }^{1}$ Zob. F. S. P. Dufour, Historia prostytucji od czasów najdawniejszych do XX w. T. 1. Gdynia 1997, s. 25. Autor twierdzi, że kolebką prostytucji jest Chaldeja, ojczyzna Abrahama, gdzie prostytucja była elementem gościnności.

${ }^{2}$ Zob. Kpł 19, 28; Pwt 23, 18n.

3 Zob. Rz 1, 22-27.

${ }^{4}$ Z pisarzy kościelnych tylko Klemens Aleksandryjski stawia małżeństwo wyżej niż dziewictwo. Zob. Kobierce, VII, 12, 70. Warszawa 1994, s. 274n. 
mę życia5. To, między innymi, stało się przyczyną rozwoju życia monastycznego i zakonnego.

Stosunek Kościoła do prostytucji trudno byłoby określić jednym stwierdzeniem. Szacunek względem nawróconych jawnogrzesznic, które czasami stały się wielkimi świętymi, pomoc kobietom upadłym moralnie, przeplatały się z pogardą wobec samej plugawej profesji. Zawsze jednak chrześcijanie słyszeli słowa swego Założyciela: celnicy i nierządnice wchodzą przed wami do Królestwa niebieskiego ${ }^{6}$. Trudno było też nie pamiętać o nierządnicach ze Starego Testamentu: Tamar i Rahab7. Życiorysy Marii Magdaleny, Marii Egipcjanki czy św. Pelagii również nie były bez wpływu na chrześcijaństwo ${ }^{8}$.

Najbardziej wpływowy ojciec Kościoła zachodniego - św. Augustyn - także odniósł się do problemu prostytucji, pociągając za sobą wielu teologów katolickich. Szczególnie znane jest zdanie Doktora Łaski z drugiej księgi traktatu De ordine, gdzie wyraźnie mówi: „Aufer meretrices de rebus humanis, turbaveris omnia libidinibus". To zdanie oddało podejście starożytnego Kościoła do prostytucji. Św. Augustyn po prostu wyraził opinię sobie współczesnych. Stanowisko to przetrwało do czasów św. Tomasza z Akwinu, a dzięki niemu dalej jeszcze było aktualne.

Bardzo interesujące z kolei jest stanowisko wobec nierządu u Słowian. Ibrahim ibn Jakub był wręcz zdziwiony tym, co zobaczył, podróżując przez ziemie słowiańskie w X wieku. Pisał, że gdyby pan młody odkrył, że jego wybranka jest w chwili ślubu dziewicą, odesłałby ją do rodziców, mówiąc, iż jest ona taką, ponieważ nikt jej nie chcia $1^{10}$. Sytuacja zmieniła się z chwilą przyjęcia chrześcijaństwa, które powoli wprowadzało konsekwentnie nowy kodeks postępowania. Jednakże długo jeszcze po chrzcie w 966 roku problem prostytucji w Polsce pozostawał realny.

5 Zob. Sobór Trydencki, Kanony o sakramencie małżeństwa, kan. 10. W: Dokumenty soborów powszechnych. T. 4. Kraków 2004, s. 718n.

6 Zob. Mt 21, 31n.

7 Zob. Rdz 38; Joz 6, 17. Obie nierządnice są umieszczone w genealogii Jezusa w Mt 1, 3 oraz 1, 5.

${ }^{8}$ Maria Egipcjanka (344-421), gdy miała 12 lat została prostytutką i prowadziła takie życie przez 17 lat. Udała się na pielgrzymkę do Ziemi Świętej, aby zwodzić pielgrzymów na złą drogę, jednak podróż ta skończyła się jej nawróceniem i pokutą. Św. Maria z Egiptu wspominana jest 1 kwietnia, jej życie znane jest z żywota, który napisał św. Sofroniusz. Św. Pelagia zginęła w czasie prześladowania za Dioklecjana, była tancerką i kurtyzaną, gdy usłyszała kazanie św. Nonnusa o straszliwym sądzie, porzuciła hańbiący sposób życia i podjęła pokutę.

9 Aurelius Augustinus, De ordine. II, 4, 12 (Patrologiae cursus completus. Series Latina [dalej: PL]. Ed. J. P. Migne. T. 1-221. Parisiis 1844-1864, tutaj: 32, 1000).

${ }^{10}$ Zob. Relacja Ibrahima ibn Jakuba z podróży do krajów słowiańskich. Wyd. T. Kowalski. Kraków 1946, s. 53. 
Świadczy o tym choćby sprowadzenie w 1217 roku sióstr magdalenek, mających za zadanie pomoc upadłym dziewczętom ${ }^{11}$. Prawodawstwo różnych miast starało się ograniczać prostytucję. Tak było w Krakowie, szczególnie w końcu XIV wieku.

Wówczas $\mathrm{w}$ Krakowie istniały trzy domy publiczne, działające $\mathrm{w}$ pobliżu obecnego Gródka, w miejscu zwanym Belza (in Belsa) ${ }^{12}$. Niektóre nierządnice, pracujące tam, były znane z imienia, jak Katusza czy Dorota. Rok 1398 był w pewien sposób przełomowy dla owych trzech domów. Wówczas bowiem rada miasta wydała ustawę, na mocy której meretrices zostały usunięte z Krakowa ${ }^{13}$. Samo usunięcie okazało się bezskuteczne. Co prawda miejsce po lupanarach zostało wynajęte przez nowego dzierżawcę, jednakże nie oznaczało to pozbycia się problemu prostytucji. I to był powód, dla którego rada miejska zwróciła się do sfer kościelnych z pytaniem, które przytacza ks. Jan Fijałek w swojej książeczce o Biskupcu i Falkenbergu' ${ }^{14}$ : „Czy miasto może stawiać i utrzymywać domy nierządu, i to na czynsz roczny lub bez niego?". Osobą, do której wystosowano to pytanie, był Jan Falkenberg, który jako regens dominikańskiego Studium był uważany za kogoś kompetentnego ${ }^{15}$. Musiał on być cenionym teologiem, gdyż jak wspomina ks. Fijałek, sprawa była „nadzwyczaj zawiła, drażliwa i niepokojąca sumienie chrześcijańskie ojców miasta Krakowa" ${ }^{16}$.

Jan Falkenberg urodził się w połowie XIV wieku w Falkenburgu ${ }^{17}$ był dominikaninem, synem Prowincji Polskiej. Dobrze wykształcony w rodzinnej miejscowości, nadto w Pradze, Wiedniu, Kamieniu Pomorskimª ${ }^{18}$ a w końcu w Paryżu. Przejawiał wyjątkową wręcz skłonność do wdawania się w coraz to bardziej skom-

${ }^{11}$ Zob. E. Karabin, Najstarszy problem Kościoła. „Więź” R. 52: 2009, nr 8/9, s. 50-6o.

${ }_{12}$ Zob. J. Kracik, M. Rożek, Hultaje, złoczyńcy, wszetecznice w dawnym Krakowie. Kraków 2010, s. 132n.

${ }^{13}$ Zob. J. Fijałek, Dwaj dominikanie krakowscy: Jan Biskupiec i Jan Falkenberg. Lwów 1925, s. 34.

${ }_{14}$ Tamże.

${ }^{15}$ J. Turek swoim artykule, w oparciu o odpowiedź Falkenberga na pytanie władz miejskich Krakowa, stara się ustalić datę powstania dominikańskiego Studium. Zob. J. Turek, Regens krakowski Jan $z$ Soboru Pizańskiego w świetle dwóch traktatów Jana Falkenberga, „Przegląd Tomistyczny” T. 16: 2010, s. 46n.

${ }^{16}$ J. Fijałek, Dwaj dominikanie..., s. 34.

${ }^{17}$ W pracy ks. J. Fijałka Dwaj dominikanie krakowscy: Jan Biskupiec i Jan Falkenberg pojawiają się jeszcze trzy możliwe pisownie tej miejscowości: Falkenburg, Falkinborg oraz Falkinberg. Zob. tamże, s. 31 .

${ }^{18}$ Długosz podaje, że Falkenberg był dominikaninem zarówno z diecezji, miasta, jak i konwentu kamienieckiego. Zob. J. Długosz, Roczniki czyli kroniki sławnego Królestwa Polskiego. Księga jedenasta (1415-1430). Warszawa 1985, s. 70. 
plikowane spory, czy to z Mateuszem z Krakowa, z powodu którego został wygnany z miasta pochodzenia swego adwersarza, czy to z Władysławem Jagiełłą ${ }^{19}$, czy z papieżem Grzegorzem XII ${ }^{20}$. Obecny był na Soborze w Pizie i Konstancjii ${ }^{21}$. W klasztorze krakowskim był lektorem oraz regensem Studium Polskiej Prowincji Zakonu Kaznodziejskiego, aż do czasu wygnania z Krakowa w 1407 roku.

Do tegoż sławnego Jana Falkenberga zwróciła się rada miejska, aby wyjaśnić ową niepokojącą sprawę istnienia domów publicznych, zwanych po łacinie prostibula względnie prostibulae ${ }^{22}$. Jak podaje Jacques Rossiaud w swojej książce

${ }^{19}$ Edycję Satyry Falkenerga, która potępiała króla polskiego i Polaków, zob. w: H. Boockmann, Johannes Falkenberg, der Deutsche Orden und die polnische Politik: Untersuchungen zur politischen Theorie des späteren Mittelalters mit einem Anhang: Die Satira des Johannes Falkenberg. Göttingen 1975; S. Włodek, Odnaleziona Satyra Falkenberga. „Studia Historyczne” T. 14: 1971, s. 477-491; S. Włodek, Iohannis Falkenberg Satira contra hereses et cetera nephanda Polonorum et eorum Regis Jaghel. Ed. Z. Włodek. W: La Satire de Jean Falkenberg. Texte inédit avec introduction. „Mediaevalia Philosophica Polonorum" T. 18: 1973, s. 51-95.

${ }_{20}$ Zob. J. Fijałek, Dwaj dominikanie..., Lwów 1925, s. 40.

${ }^{21}$ K. Ożóg, Uczeni w monarchii Jadwigi i Władysława Jagiełly (1384-1434). Kraków 2004, s. 26n.; B. Bess, Johannes Falkenberg OP und der preussisch-polnische Streit vor dem Konstanzer Konzil. „Zeitschrift für Kirchengeschichte” T. 16: 1896, s. 385-464; J. Turek, Regens krakowski Jan $z$ soboru pizańskiego $w$ świetle dwóch traktatów Jana Falkenberga. „Przegląd Tomistyczny” T. 16: 2010, s. 43-58.

${ }^{22}$ Samo słowo występuje w bardzo wczesnej łacinie, funkcjonuje w literaturze już za czasów Plauta (250-184 p.n.e.): „Bellum et pudicum vero prostibulum popli / post si quis vellet, te haud non velles dividi” (Aularia 2, 4, 6). W podobnym znaczeniu zostało użyte jeden raz w Wulgacie, w Kpł 21, 7n: „Scortum et vile prostibulum non ducent uxorem, nec eam quæ repudiata est a marito: quia consecrati sunt Deo suo, et panes propositionis offerunt”. W dwóch, wyżej wymienionych kontekstach prostibulum oznacza po prostu prostytutkę. Arnobiusz Afrus w księdze szóstej (13.5) swego dzieła Adversus nationes, używa prostibulum na określenie mężczyzny prostytuującego się: „Atque ita perducta est res eo ut pro diis immortalibus sacra meretricibus fierent et infelix religio signorum fabricationibus falleretur. Inter significes ille memoratus Phidias est primus: cum Olympii formam Iovis molimine operis extulisset inmensi, super dei digito: 'PANTARCES - inscripsit - PULCHER' - nomen autem fuerat amati ab se pueri atque obscena cupiditate dilecti - neque ullo metu est aut religione commotus deum nomine prostibuli nuncupare, quinimmo exoleto Iovis numen simulacrumque sacrare”. Św. Izydor w księdze XVIII Etymologii, De bellis et ludis, pisząc o teatrze, dorzuca: „Idem vero theatrum, idem et prostibulum, eo quod post ludos exactos meretrices ibi prostrarentur” . Tutaj wyraźnie ma na myśli miejsce uprawiania nierządu. Prostibulum w znaczeniu miejsca występuje także w Wulgacie: „Et accidit post omnem malitiam tuam (Vae, vae tibi! ait Dominus Deus), et aedificasti tibi lupanar, et fecisti tibi prostibulum in cunctis plateis” (Ez 16, 23n), oraz „Et dabo te in manus eorum, et destruent lupanar tuum, et demolientur prostibulum tuum” (Ez 16,39), a także: „Et super populum meum miserunt sortem; et posuerunt puerum in prostibulo, et puellam vendiderunt pro vino ut biberent" $(\mathrm{Jl} 3,3)$. 
Prostytucja $w$ średniowieczu, owe lupanary, prostibula, były najczęściej budowane na koszt całej społeczności, z pieniędzy publicznych, oddawane w dzierżawę tak zwanej przeoryszy, względnie zarządcy, którzy mieli za zadanie przyciągać dziewczęta do tej haniebnej profesji, troszczyć się o porządek i zachowanie, nadanego z góry przez zarządców miast, prawa ${ }^{23}$.

Terminem ad quem, czy raczej ante quem, zwrócenia się rady miejskiej z tą delikatną kwestią do Falkenberga był rok 1405. Na ten bowiem rok datowany jest Iudicium de aedificandis domis pro meretricibus ${ }^{24}$. Rękopis tego dziełka znajduje się w Acta Consularia Archiwum Miasta Krakowa ${ }^{25}$. Nie ma źródeł mówiących o dacie, kiedy Falkenberg został poproszony o odpowiedź na to pytanie ${ }^{26}$.

Janowi Falkenbergowi zostały zadane dwa pytania: czy ludzkie ustawy w sposób prawy dopuszczają istnienie nierządnic oraz czy pan miasta lub radni mogą budować domy publiczne, umieszczać tam prostytutki i czerpać z tego tytułu roczne zyski. Dlatego odpowiedź składa się z dwóch części, w pierwszej jest to respons na pytanie o dopust istnienia prostytutek, w drugiej odpowiedź co do istnienia lupanarów. Jednakże w Archiwum Miasta Krakowa ów dokument jest zatytułowany Osąd, dotyczacy budowy domów publicznych dla nierządnic.

Treścią Iudicium jest argumentacja pokazująca, że nierząd i istnienie lupanarów są sprzeczne z prawem Bożym. Argumenty biblijne zostały zaczerpnięte z Pierwszego Listu św. Pawła do Koryntian oraz z ksiąg starotestamentalnych: Powtórzonego Prawa, Tobiasza, Ezechiela i Micheasza. Wszędzie tam jest wyraźny zakaz nierządu, cudzołóstwa oraz czerpania z tego zysku. Falkenberg bardzo wyraźnie to podkreśla. Co do argumentów odnośnie do dopuszczania nierządu przez prawo ludzkie, dominikański regens odwołuje się do autorytetu św. Augustyna, św. Grzegorza Wielkiego, do Dekretów Gracjana oraz Arystotelesa. Św. Augustyn jest cytowany na podstawie dwóch dzieł: $O$ wolnej woli oraz O porządku.

Falkenberg, znając Summę teologii św. Tomasza z Akwinu, raczej na niej opiera swój wywód ${ }^{27}$. W Prima Secundae Summy, w kwestii 96, rozważającej, czy zadaniem ludzkiego prawa jest tępienie wszystkich wad i występków, Dok-

${ }^{23}$ Zob. J. Rossiaud, Prostytucja w średniowieczu. Warszawa 1997, s. 13.

${ }^{24}$ Zob. W. Seńko, Trzy traktaty Jana Falkenberga na temat tyranobójstwa przedstawione na soborze w Konstancji 1416 r. „Przegląd Tomistyczny” T. 10: 2004, s. 89.

${ }_{25}$ Tamże.

${ }^{26}$ Jan Fijałek, jak to twierdził Władysław Seńko, błędnie datował tekst Falkenberga na rok 1398 i sugerował, że został on wydany w Krakowskich Aktach Posiedzeń. Takie wydanie, jak zapewniał W. Seńko, nie istnieje w tym zbiorze.

${ }_{27}$ Zob. Thomas de Aquino, Sth I-II. q. 96 (Editio Leonina. T. 7. Romae 1892, s. 187). 
tor Anielski dwukrotnie cytuje opinię św. Augustyna z traktatu O wolnej woli: „Prawo owe, które jest dane do władania państwami, dopuszcza, a także pozostawia bez kary wiele rzeczy, które jednak zostają pomszczone przez Opatrzność boską; i dobrze. Z tego powodu, że [prawo] nie zakazuje wszystkiego, to, czego zakazuje, nie powinno być negowane" ${ }^{28}$. Główne rozumowanie wywodu Akwinaty opiera się jednak na Arystotelesie i św. Izydorze, którzy twierdzili, że prawo powinno być dostosowane do ludzi, żyjących według niego. Innymi słowy, prawo musi być możliwe do przestrzegania. Tomasz mówi, że inne jest prawo dla człowieka o wyrobionej cnocie, inne dla człowieka o cnocie niedoskonałej. Podobnie jak inne jest prawo dla dzieci i inne dla dorosłych. Akwinata jest zdania, że „prawo ludzkie nadawane jest wielu ludziom, z których większa część to ludzie o niedoskonałej cnocie”"29. Prawo ludzkie zatem nie zabrania wszystkiego, od czego stronią ludzie uformowani moralnie, ale tylko cięższych występków, których mogą się powstrzymać także ludzie mniej cnotliwi. Zakaz bowiem popełniania tych przestępstw jest konieczny do poprawnego funkcjonowania społeczności.

Tomasz z Akwinu jest świadomy ułomności ludzkiej natury. W żaden jednak sposób nie usprawiedliwia występku. Doktor Powszechny zdaje sobie sprawę, że wiele ludzi nie jest w stanie, albo lepiej mówiąc, nie chce powstrzymać się od niektórych przestępstw. Tomasz widzi w prawie ludzkim nie tyle szczyt i ideał, co pewien środek, który stopniowo ma prowadzić ludzi do doskonałości, do całkowitej nienawiści zła i wyboru dobra. Akwinata mówi, że gdyby od razu prawo ludzkie narzucało na wszystkich obowiązek powstrzymywania się od wszelkiego zła, wówczas ludzie niewypróbowani jeszcze bardziej stoczyliby się na dno, a przecież prawo ma za zadanie ich także prowadzić do doskonałości.

Argumenty mówiące, dlaczego dopuszczone jest zło, są wprost wyrażone w Summie teologi $i^{30}$. Secunda Secundae w jedenastym artykule dziesiątej kwestii, w odpowiedzi na pytanie, czy należy tolerować obrzędy niewierzących, mówi, że Bóg dopuszcza zło, aby nie zniszczyć jakiegoś większego dobra, albo też, aby nie wyniknęło $z$ tego gorsze zło.

W podobną argumentację wchodzi Jan Falkenberg. Konsekwencją zupełnego zakazu nierządu byłoby znacznie gorsze zło - wiarołomstwo małżeńskie ${ }^{31}$,

\footnotetext{
${ }_{28}$ Tamże, a. 2, sc oraz ad 3 (s. 187-188).

29 Tamże, resp. (s. 187).

30 Thomas de Aquino, Sth II-II. q. 10, a. 11, resp. (Editio Leonina. T. 8. Romae 1895, s. 92-93).

${ }^{31}$ Łac. adulterium.
} 
gwałty, uwiedzenia etc. W żadnym wypadku nierząd nie może być aprobowany, dopuszczany jako coś pozytywnego. Jednakże można go tolerować, aby powstrzymać niektórych ludzi od znacznie cięższych występków. Można dostrzec, że w ówczesnym społeczeństwie bardzo istotną rolę odgrywa życie rodzinne. $Z$ powodu ochrony cudzych żon i córek dopuszcza się, by niektórzy mężczyźni chodzili do domów publicznych. Kolejne spostrzeżenie dotyczy społeczności. Dopuszcza się istnienie w niej domów publicznych, aby mogła ona funkcjonować w sposób odpowiedni, aby nie zniszczyć jej przez pożądanie. Popularne było wówczas twierdzenie, że prostytucja odgrywa rolę kloaki. Gdyby jej nie było, cały pałac cuchnąłby nieznośnym odorem lubieżności.

$\mathrm{Z}$ dzisiejszej perspektywy być może należałoby negatywnie ocenić ówczesne podejście do nierządnic. Były one potraktowane instrumentalnie, jako konieczne zło. Mistrzowie średniowieczni, a wśród nich Jan Falkenberg, zapewne nie zastanawiali się nad losem prostytutek i ich degradacją zarówno osobową, jak również poniżeniem w ówczesnym społeczeństwie. Z drugiej strony, trudno na podstawie tego krótkiego Iudicium oceniać całokształt poglądów Falkenberga na temat prostytucji i prostytutek, tym bardziej że nie o to został zapytany przez radę miejską. Wspomniane siostry magdalenki z 1217 roku oraz wiele innych zgromadzeń zakonnych i stowarzyszeń religijnych podejmowało się wyciągania kobiet z tej plugawej pracy. Nigdy w Kościele nie brakowało ludzi, którzy umieli współczuć najbardziej pogardzanym i wyciągać ich z ich upadłego sposobu życia.

Jednakże traktacik Jana Falkenberga też nie jest bez znaczenia. To, że dopuszcza istnienie domów publicznych, że dopuszcza pewną formę opieki miasta nad nierządnicami, być może jest również pewnego rodzaju aktem miłosierdzia i pierwszym stopniem pomocy upadłym kobietom. Nawet po usunięciu owych trzech domów in Belsa w 1398 roku prostytucja w Krakowie istniała. Gdyby bowiem problem był zupełnie rozwiązany, rada miejska nie zwróciłaby się z tymi dwoma pytaniami do regensa dominikańskiego Studium. Prostytutki żyły w skrajnie ubogich warunkach, bez żadnej nadziei na zmianę losu. Kto wie, czy tekst Falkenberga nie przyczynił się do realnej pomocy nierządnicom, które bez godziwych warunków i tak uprawiałyby swoje niegodziwe zajęcie. 


\section{Jan Falkenberg}

\section{Osąd, dotyczący budowania domów publicznych dla nierządnic}

[Podstawa tłumaczenia: Joannes Falkenberg, Iudicium de aedificandis domis pro meretricibus. Ed. W. Seńko. W: tenże, Trzy traktaty Jana Falkenberga na temat tyranobójstwa przedstawione na soborze w Konstancji 1416 r. „Przegląd Tomistyczny” T. 10: 2004, s. 124-126]

Odpowiedź mistrza Jana Falkenberga, brata Zakonu Kaznodziejów, profesora świętej teologii, regensa Studium Krakowskiego domu tegoż [Zakonu].

Czy słusznie prawo ludzkie dopuszcza istnienie nierządnic? Sądzę, że należy odpowiedzieć jak odpowiadam, przez ten dwuczłonowy wniosek: Chociaż prawo boskie zabrania istnienia nierządnic i zbliżania się do nich, to jednak prawo ludzkie słusznie dopuszcza i toleruje ich istnienie. Część pierwsza jest dowodzona przez owe słowa Apostoła, z Pierwszego Listu do Koryntian z rozdziału szóstego: „uciekajcie przed cudzołóstwem ${ }^{32}$ oraz [słowa] księgi Tobiasza (w rozdziale czwartym): uważaj - to jest strzeż się - synu <mój> wszelkiego cudzołóstwa" ${ }^{33}$, a księga Powtórzonego Prawa (w rozdziale dwudziestym trzecim [mówi]): „Nie będzie nierządnicy z córek Izraela ani rozpustnika z synów Izraela $^{34}$; o czym mówi Glossa: w sposób oczywisty zakazuje mężom i niewiastom uprawiać nierząd" ${ }^{35}$. A zatem pokazuje swoim małżonkom, że grzechem jest współżycie nie $\mathrm{z}$ własnym małżonkiem, gdyż zabrania istnienia nierządnic oraz chodzenia do tych [kobiet], których sromota publicznie jest sprzedawana. Zatem pierwsza część [jest] prawdziwa.

A druga [część] jest dowodzona w podobny sposób. Skoro bowiem ludzka władza pochodzi od władzy boskiej i ją powinna naśladować, Bóg zaś, chociaż jest wszechmocny i w najwyższym stopniu dobry, dopuszcza jednak, że pewne zło zdarza się we wszechświecie, (którego mógłby [przecież] zakazać), by przez zniesienie go większe dobro nie zostało zniszczone, albo by nie wyniknęło gorsze zło. Tak też [jest] we władzy ludzkiej. Ci, którzy dobrze rządzą, dopuszczają i znoszą niektóre zło, aby jakieś dobro nie zostało naruszone, albo też, aby nie zdarzyło się gorsze zło. Albowiem gdyby chcieli je odeprzeć, podążaliby za wszel-

\footnotetext{
${ }^{32} 1$ Kor $6,18$.

${ }^{33}$ Tob $4,13$.

${ }^{34}$ Pwt 23, 17 .

35 Glossa ordinaria in Deut. XXIII 17 (PL 113, 631).
} 
kim złem, w taki sposób, że także liczne dobro mogłoby być zniszczone, a używanie dobra wspólnego, które jest konieczne do nawrócenia ludzkiego, [mogłoby być] naruszone. I dlatego [tak] jest, że prawo ludzkie nie może wszelkiego zła, które się dzieje, zwalczyć albo zakazać, jak mówi Augustyn w pierwszej księdze O wolnej woli, że „prawo owe, które jest dane do władania państwami, dopuszcza, a także pozostawia bez kary wiele rzeczy, które jednak zostają pomszczone przez Opatrzność boską; i dobrze. $Z$ tego powodu, że [prawo] nie zakazuje wszystkiego, to, czego zakazuje, nie powinno być negowane" ${ }^{36}$. I tak nierządnice, $\mathrm{w}$ ten sam sposób, choć prawo boskie je karze i zabrania im istnieć, to jednak prawo ludzkie w sposób odpowiedni je dopuszcza, aby większe odstępstwa nie zdarzyły się albo [też], żeby nie wyniknęło większe zło, jakim jest wiarołomstwo małżeńskie, gwałt, uprowadzenie, kazirodztwo albo inna nieczystość.

Przecież mówi Augustyn w drugiej księdze $O$ porządku: „usuń nierządnice ze świata ludzkiego, a zmącisz wszystko pożądliwością" ${ }^{37}$. Nie należy też w to wierzyć, że prawo ludzkie przeciwstawia się prawu boskiemu, z tego powodu, że dopuszcza istnienie nierządnic, nie tyle jakby je aprobując, co jakby nie będąc w stanie kierować nimi. Liczne bowiem rzeczy są rządzone prawem boskim, którymi prawo ludzkie nie jest w stanie kierować. Zdarza się na podstawie porządku prawa wiecznego, że wiele rzeczy jest poddanych nadrzędnej przyczynie, jakby wzorowi i to także, że prawo ludzkie nie miesza się do tego, czym kierować nie może. Zatem w tym się prawu boskiemu nie przeciwstawia. Byłoby jednak czymś niewłaściwym, gdyby prawo ludzkie aprobowało to, co odrzuca prawo boskie. Zatem nie wynika [stąd], że prawo ludzkie przeciwstawia się prawu boskiemu, lecz, że doskonale nie jest w stanie go dosięgnąć.

A zatem, co do drugiej części wniosku, tak dowodzę: „należy wybrać mniejsze zło $\mathrm{z}$ dwóch, kiedy do jednego $\mathrm{z}$ nich ktoś jest zmuszony sytuacją ${ }^{38}$, według Grzegorza w 35 księdze Moraliów, w rozdziale dziesiątym oraz według Filozofa w trzecim rozdziale trzeciej księgi Etyki ${ }^{39}$, oraz według Dekretów [Gracjana] Dwa $z ł a^{40}$. Zaś Apostoł, ze względu na niepowściągliwość niektórych, dopuścił najmniejsze zła, aby odwrócili się od większych. W Pierwszym Liście do Koryntian,

${ }^{36}$ Augustinus Aurelius, De libero arbitrio, I, 5, 13 (PL 32, 1228).

${ }_{37}$ Tenże, De ordine, II, 4, 12 (PL 32, 1000).

${ }^{38}$ Gregorius Magnus, Moralia in Job, 35, 10 (PL 75, 612).

39 Arystoteles, Etyka nikomachejska, III, 5, 1114a25.

${ }^{40}$ Zob. Decretum Gratiani. Pars I, d. 13, c. 1 (Corpus Iuris Canonici. Ed. E. Friedberg. T. 1. Leipzig 1879, kol. 31): „Duo mala, licet cautissime sint precauenda tamen si periculi necessitas unum ex his temperare compulerit, id debemus resoluere, quod minori nexu noscitur”. 
w rozdziale siódmym: „ze względu na cudzołóstwo - mówi - każdy jeden niech ma własną żonę, a każda jedna niech ma swego męża. To jednak - mówi - mówię, postępując za pobłażliwością, a nie za rozkazem" ${ }^{41}$, aby pokazać to, co dopuścił bez winy, chociaż najmniejszym nie było. A przecież jest mniejszym złem uprawiać rozpustę z nierządnicą, niż dopuścić się wiarołomstwa małżeńskiego, gwałtu, albo innych większych rzeczy, które miałyby tę przyczynę, że [mężczyźni] najwięcej płonęliby, [z tego powodu, że] usunięte zostały nierządnice, gdyż: „usuń nierządnice ze świata ludzkiego, a zmącisz wszystko pożądliwością". I dlatego prawo ludzkie słusznie dopuszcza istnienie nierządnic i współżycie z nimi, aby uniknąć wiarołomstw małżeńskich, gwałtów, i innych większych nieczystości, jak to mówi Augustyn w pierwszej księdze $O$ wolnej woli, że „prawo w tym ludzie, którym kieruje, daje pozwolenie na mniejsze występki, aby nie pozwalać na większe" etc. ${ }^{42}$

\section{Odpowiedź tegoż [Jana Falkenberga] na drugą kwestię}

Czy pan miasta lub radni mogą budować domy publiczne i zapełniać je nierządnicami na roczny czynsz albo bez niego?

Przez poprzednią odpowiedź wystarczająco [wszystko] zostało powiedziane. Rzekłem bowiem, że prawo ludzkie nie powinno aprobować nierządnic; a ponieważ budowa domów publicznych i zapełnianie ich nierządnicami na roczny czynsz jest aprobacją nierządnic z powodu sromotnego zysku; a zatem nie wolno, lecz jest [to] grzech. I dowodzi się [tego w ten sposób]: Budowanie domów publicznych nierządnicom, czy to dla wsparcia nierządu, czy dla czerpania stamtąd czynszu potępia prorok; najpierw Ezechiel w szesnastym rozdziale: „wybudowałeś sobie lupanar i zrobiłeś sobie dom publiczny na każdym placu” ${ }^{43}$, drugi Micheasz: „wszelkie zyski jego będą spalone ogniem, a wszystkie idole jego dam na zagładę, ponieważ z zapłaty za nierząd zostały zgromadzone" ${ }^{44}$. A zatem w żaden sposób nie wolno budować domów publicznych i zapełniać ich nierządnicami na roczny czynsz. A jednak, jak stwierdziłem w pierwszej odpowiedzi, prawo

\footnotetext{
${ }^{41} 1$ Kor 7, 2; 7, 6.

${ }^{42}$ Augustinus Aurelius, De libero arbitrio, I, 5, 11 (PL 32, 1228).

${ }^{43} \mathrm{Ez}$ 16, 24.

${ }^{44}$ Mi 1, 7.
} 
ludzkie słusznie dopuszcza i toleruje istnienie nierządnic, zatem także słusznie pozwala i dopuszcza to, co jest im konieczne do zachowania życia, mianowicie utrzymanie, i odzienie, i domy, dzięki którym są chronione przed deszczem i od skwaru, dlatego że bez nich nie mogłyby istnieć. A być może żaden obywatel nie chce im, z powodu wielkiej sromoty, albo też nie mógłby na podstawie własnego autorytetu, lokować domów. A zatem pan albo radni miasta w sposób godziwy mogą im lokować domy, i jeśli [ich] nie ma, to [można] budować, aby uniknąć większego zła, które by wynikło, gdyby je usunęli. Z tego powodu podlegający temu [prawu], nie ma grzechu, chcieliby bowiem najgorliwiej, gdyby to było możliwe dla nich, ustrzec się nierządnic i innych, bardziej złych rzeczy, które wynikają z usunięcia ich. A ponieważ konieczność niebezpieczeństwa zmusza dokonać jednego $\mathrm{z}$ nich, mianowicie nierządu albo większego zła, a zatem w sposób godziwy mogą, a nawet powinni chcieć dopuścić [to]. Zresztą i w sposób odpowiedni dopuszczają i zachowują nierządnice w domach i innych, bez których nie mogłyby przetrwać, i większego zła, które po ich usunięciu wynikłoby w mieście, unikają i powstrzymują [je].

\section{Summary}

The problem of prostitution in the medieval Cracow.

\section{Iudicium de aedificandis domis pro meretricibus by John Falkenberg}

The author focuses on the question of prostitution in the medieval Cracow in the light of edited-by- himself treaty by John Falkenberg Iudicium de aedificandis domis pro meretricibus. Writing his treaty Falkenberg was trying, at the request of the Municipal Council, answer the following questions: do laws established by people allow the existence of prostitutes, and: can the ruler of the city or councillors build brothels, put prostitutes there and then profit from such business. The text contains a short review of the problem of prostitution in Cracow of that time as well as the explanati of a context in which Falkenberg's work was written. In the last part of the article, the author presents a two-part edition of the treaty. 